\title{
Effect of Citric Acid on the Oxidative and Flavor Stability of Soybean Oil
}

\author{
Koji Miyakoshi, Mamoru Komoda, and \\ Shigezo Matsubara \\ Sugiyama Chemical and Industrial Laboratory \\ (11, Kagetori-cho, Totsuka-ku, Yokohama)
}

\begin{abstract}
Citric acid was added into the deodorized soybean oil. Citric acid content in the oil was determined by GLC wtih 5\% Silicone OV-17 and the effect of citric acid on the oxidative and flavor stability of the soybean oil was tested. Citric acid did not protect the oil against fluorescent light. On the other hand, citric acid markedly improved flavor and oxidative stability when the oils were deteriorated under spontaneous autoxidation conditions. However, its efficiency was independent of its concentration. Citric acid solubility in the soybean oil was measured. At least $50 \mathrm{ppm}$ citric acid could be dissolved in the oil after 4 weeks of storage.
\end{abstract}

\section{Introduction}

For many years, citric acid has been used as synergist of antioxidants for edible oils and fats. Many workers reported studies of the use of citric acid in edible oils and fats. Cowan and Evans ${ }^{1)}$ insisted that citric acid acts entirely as a metal-chelating agent. On the other hand, Lundberg's and Lemon et $a l^{3)}$ described that citric acid functions not only as a metal-scavenger but also as a socalled acidic synergist like ascorbic acid. Privett and Quackenbush ${ }^{4}$ considered that citric and ascorbic acids function as synergists in natural fats and oils by inhibiting the antioxidant catalysis of peroxide decomposition. However, these published papers do not refer to the citric acid content in the oils.

The authors reported in the previous paper $^{5)}$ that thermally decomposed products, of citric acid i.e., aconitic, itaconic, and citraconic acid are not formed in the commercial edible oils. Therefore, citric acid alone can be expected to act as a synergist. We also reported that citric acid is decomposed when added during deodo $=$ rization. Therefore, the relationship between citric acid content and oxidative stability of fully refined edible oils is very important. Because the oils which contain no citric acid serve poor quality for flavor and oxidative stability.

When soybean and other oils containing linolenic acid are exposed to air for long periods, off-flavors are developed. ${ }^{1)}$ A large amount of soybean oil is used for salad and frying oils. Therefore, clarification of flavor reversion mechanism and its inhibition is necessary. Thus, we have made the laboratory experiments to investigate the effect of citric acid on the oxidative and flavor stability of soybean oil.

\section{Experimental procedure}

\subsection{Deodorization}

General features of the bleached soybean oil, manufactured commercially, are shown in Table-1. Tocopherol and iron contents in the oil were determined by the method of Nelson and Milun ${ }^{6)}$, and Evans et al.," respectively.

The bleached soybean oil was deodorized in the glass laboratory deodorizer. The deodoric zation conditions were as follows: temperature, $260^{\circ} \mathrm{C}$; vacuum, $5 \mathrm{mmHg}$; time, $1 \mathrm{~h}$; and steam, $3 \%$. Citric acid aqueous solution was added into the oil at the beginning or during cooling phase of deodorization.

2.2 Determination of citric acid by GLC Soybean oil $(50 \mathrm{~g})$ containing citric acid was 
taken into a $500 \mathrm{ml}$ separatory funnel. Hexane $(100 \mathrm{ml})$ and $50 \mathrm{ml}$ of distilled water were added into the funnel to extract the citric acid. The funnel was automatically shaken for $1 \mathrm{~h}$. The water layer containing citric acid was collected through a filter paper. The aqueous solution $(25 \mathrm{ml})$ was pipetted to a $50 \mathrm{ml}$ round bottom flask and was neutralized with $0.1 \mathrm{~N}$ sodium hydroxide.

After the water was evaporated, the citric acid in the flask was esterified with $2 \mathrm{ml}$ of 1-butanol, $0.2 \mathrm{ml}$ of sulfuric acid, and $2 \mathrm{~g}$ of anhydrous sodium sulfate. Then, tributyl citrate was collected into a $5 \mathrm{ml}$ test tube using hexane. The details of this paragraph are described in published paper $^{8}$.

Hexane solution $(2 \mathrm{ml})$ containing $0.2 \mathrm{mg}$ of $o$-terphenyl internal standard was added to the tube and filled up to $5 \mathrm{ml}$ with hexane. Two microliters of the sample solution were then chromatographed two times for each sample. The following GLC conditions were used:

Instrument: Shimazu GC-5A Gas Chromato= graph with a dual flame ioniza= tion detector.

Column : Glass, $3 \mathrm{~mm}$ ID, $2 \mathrm{~m}$ long, packed with $5 \%$ Silicone OV-17, Chro= mosorb W DMCS AW, 60 80 mesh.

Flow Rate: Nitrogen carrier gas, $60 \mathrm{ml} / \mathrm{min}$ to each column, hydrogen $50 \mathrm{ml} /$ $\min$ to each flame, air $100 \mathrm{ml} /$ $\min$.

Temperature: Inlet and detector temperature were $250^{\circ} \mathrm{C}$. Column oven was $220^{\circ} \mathrm{C}$.

Sensitivity: $10^{3}$.

Range: 8.

Chart speed : $10 \mathrm{~mm} / \mathrm{min}$.

\section{$2 \cdot 3$ Oxidative stability test}

Oxidative stability was assayed by determin= ing the peroxide of the soybean oil after holding it in a $60^{\circ} \mathrm{C}$ oven in the dark for 3 or $5 \mathrm{~d}$. The samples were also organoleptically evaluated following the procedure of Moser et al.. ${ }^{9)}$ After the soybean oil ( $\left.150 \mathrm{~g}\right)$ taken into the $250 \mathrm{ml}$ wide--mouthed bottles was stored at the above conditions, 10 trained panels evalu= ated the oil. The paired comparison method was employed and a 10-point scoring system was used for judging quality and intensity of flavor. $t$-Test was used to test the sample means for differences.

Oxidative stability of the soybean oil was also measured by the Active Oxygen Method, i.e., peroxide value was determined after hold= ing the oil $8 \mathrm{~h}$ under the AOM conditions, and the time required for the oil to reach peroxide value 100 was measured.

The effect of fluorescent light on the flavor deterioration of the soybean oil was examined according to the method of Moser et al. ${ }^{10}$ Soybean oil $(150 \mathrm{~g})$ was taken into the $250 \mathrm{ml}$ transparent wide-mouthed bottles, and they were placed in the fluorescent light exposure apparatus (Fig.-1). After the bottles were exposed to the light of 7000 luxes for $10 \mathrm{~h}$, organoleptic evaluation of the oil was carried out as described above. Peroxide value was
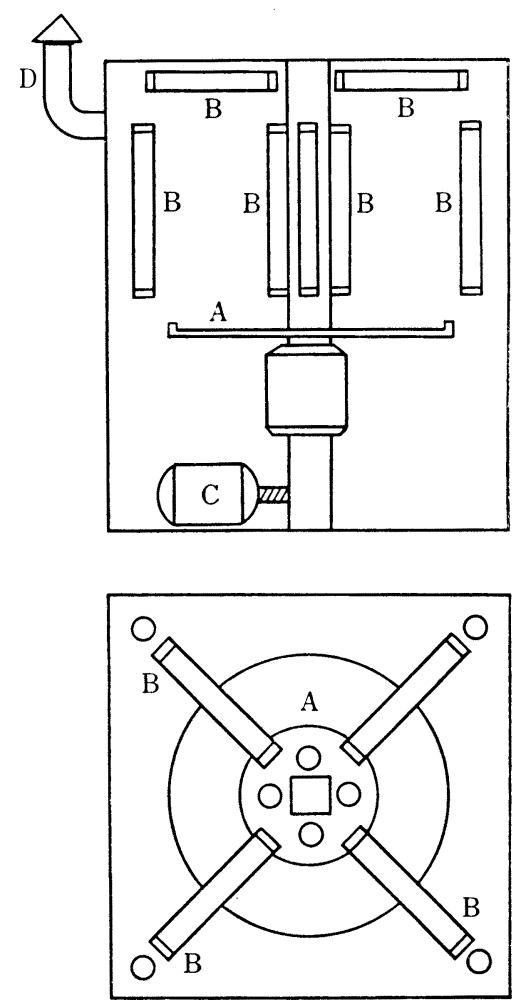

A: Rotating table on which sample. bottles are placed.

B: Fluorescent lamp $(10 \mathrm{~W} \times 12)$

C: Motor

D: Ventilator to keep the temperature constant.

Fig.-1 Fluorescent light exposure apparatus. 
also determined.

\section{Results and discussion}

\subsection{Gas chromatography}

The retention time of $o$-terphenyl and tribu $=$ tyl citrate ester were 7 and $15 \mathrm{~min}$, respectively. The calibration curve of citric acid is shown in Fig-2. ${ }^{8}$ Esterification rate of citric acid

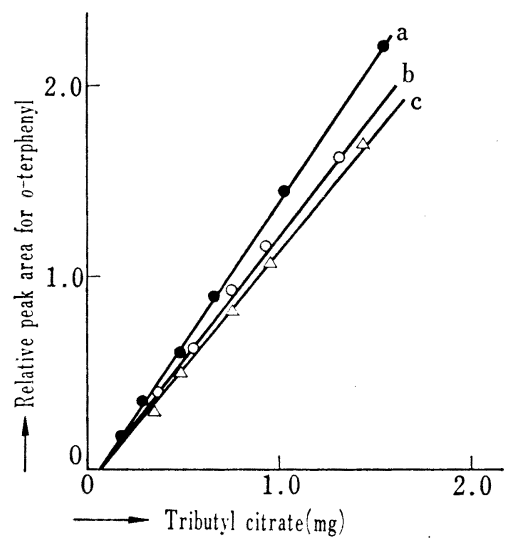

a: Standard ester, b: Esterified, c: Recovery

Fig.-2 Calibration curves of citric acid.

was $88.4 \%$. Recovery of citric acid from the oil was $94.0 \%$.

\subsection{Deodorization and citric acid addi-} tion

Citric acid (50 ppm) was added into the soybean oil at the beginning or during cooling phase of deodorization, and its effect on the oxidative and flavor stability of the soybean oil was tested. Results are given in Table-1 and2, where $\mathrm{A}, \mathrm{B}, \mathrm{C}$, and $\mathrm{D}$ were as follows:
A : Control.

B : Citric acid was added at the beginning of deodorization.

$\mathrm{C}:$ Citric acid was added at $130^{\circ} \mathrm{C}$ during cooling phase of deodorization.

$\mathrm{D}$ : Citric acid was added when the oil was cooled to $200^{\circ} \mathrm{C}$ after deodorizas tion. The temperature was maintained at $200^{\circ} \mathrm{C}$ for $10 \mathrm{~min}$, and then the oil was rapidly cooled to $30^{\circ} \mathrm{C}$

Citric acid (29.2 ppm) was found in the oil C. However, citric acid could not be detected in the oils B and D. Citric acid was decomo posed by heat during deodorization..$^{5)}$

The results of $60^{\circ} \mathrm{C}$ oven test and $\mathrm{AOM}$ test indicate that citric acid is highly effective on flavor and oxidative stability of soybean oil, which means that citric acid protects the oil against spontaneous autoxidation. Citric acid addition during cooling phase of deodorization markedly improved flavor and oxidative stabil= ity, and the stability of the oil $\mathrm{C}$ containing $29.2 \mathrm{ppm}$ citric acid was most improved. Although citric acid could not be detected in the oil $\mathrm{D}$, stability was greatly improved. It seems most likely that trace amount of citric acid which is formed metal complexes still remained in the oil $\mathrm{D}$. This result suggests that citric acid does not function as an acidic synergist such as ascorbic acid, for it is difficult to think that such trace amounts of citric acid can act as an acidic synergist. Meanwhile addi= tion of citric acid at the beginning of deodori= zation slightly improved oxidative stability.

Table-1 General characteristics of the soybean oil.

\begin{tabular}{l|l|l|l|l|c}
\hline & \multirow{2}{*}{$\begin{array}{c}\text { Bleached*1 } \\
\text { oil }\end{array}$} & \multicolumn{4}{|c}{ Deodorized oil*2 } \\
\cline { 3 - 6 } & & A control & B citric before & C citric $130^{\circ} \mathrm{C}$ & D citric $200^{\circ} \mathrm{C}$ \\
\hline Rovibond color (5 $1 / 4$ in.cell) & $20 \mathrm{Y}-5 \mathrm{R}$ & $7 \mathrm{Y}-0.9 \mathrm{R}$ & $8 \mathrm{Y}-0.9 \mathrm{R}$ & $7 \mathrm{Y}-0.8 \mathrm{R}$ & $7 \mathrm{Y}-0.9 \mathrm{R}$ \\
Peroxide value & 3.9 & 0.2 & 0.2 & 0.3 & 0.2 \\
Iodine value & 131.1 & 131.1 & 130.4 & 130.8 & 131.2 \\
Acid value & 0.07 & 0.03 & 0.02 & 0.06 & 0.02 \\
Tocopherol (ppm) & 791 & 680 & 728 & 739 & 727 \\
Iron (ppm) & & 0.04 & 0.03 & 0.03 & 0.04 \\
Citric acid (ppm) & & nil & 29.2 & nil \\
\hline
\end{tabular}

*1 Fatty acid compositions were palmitic $10.0 \%$, stearic $4.1 \%$, oleic $25.7 \%$, linoleic $52.8 \%$, and linolenic $7.4 \%$.

*2 Citric acid (50 ppm) was added into B, C, and D. 
Table-2 Effect of citric acid upon the oxidative and flavor stability of the deodorized soybean oil.*1

\begin{tabular}{c|c|c|c|c}
\hline \multicolumn{4}{c|}{ Deodorized oil } & $\begin{array}{l}\text { Signifi=*2 } \\
\text { cant } \\
\text { difference }\end{array}$ \\
\hline A control & B $\begin{array}{l}\text { citric } \\
\text { before }\end{array}$ & C citric $130^{\circ} \mathrm{C}$ & $\mathrm{D}_{200^{\circ} \mathrm{C}}^{\text {citric }}$ & \\
\hline \multicolumn{4}{|c|}{ Citric acid content $(\mathrm{ppm})$} \\
\hline & nil & 29.2 & nil & \\
\hline
\end{tabular}

Flavor score at 0 time

\begin{tabular}{l|l|l|l|l}
\hline $8.4(0.2)^{* 3}$ & $8.4(0.2)$ & $8.2(0.3)$ & $8.4(0.2)$ & + \\
\hline
\end{tabular}

Fluorescent light exposure for $10 \mathrm{~h}$

\begin{tabular}{l|l|l|l|l}
\hline $5.5(1.0)$ & $5.3(0.8)$ & & & + \\
$5.9(1.0)$ & & $5.0(1.1)$ & & + \\
$5.8(1.0)$ & & & $5.9(0.7)$ & + \\
& $6.1(1.0)$ & $6.0(1.1)$ & & + \\
& $5.6(0.8)$ & & $5.4(0.7)$ & + \\
& & $5.9(1.2)$ & $5.9(0.8)$ & + \\
\hline
\end{tabular}

After $3 \mathrm{~d}$ storage at $60^{\circ} \mathrm{C}$

\begin{tabular}{l|l|l|l|l}
\hline $5.6(8.8)$ & $6.4(3.1)$ & & & + \\
$5.4(9.4)$ & & $6.8(0.9)$ & & $*$ \\
$5.0(9.0)$ & & & $7.2(0.9)$ & $* *$ \\
\hline
\end{tabular}

After $5 \mathrm{~d}$ storage at $60^{\circ} \mathrm{C}$

\begin{tabular}{l|l|l|l|l}
$3.8(19.0)$ & $4.3(9.0)$ & & & + \\
$3.6(18.7)$ & & $6.3(2.1)$ & & $* *$ \\
$4.0(19.3)$ & & & $5.9(1.8)$ & $*$ \\
& $4.1(10.2)$ & $6.2(1.9)$ & & $* *$ \\
& $4.5(10.5)$ & & $5.6(2.5)$ & + \\
& & $6.4(2.3)$ & $5.7(2.0)$ & + \\
\hline
\end{tabular}

$\mathrm{AOM}$ (peroxide values after $8 \mathrm{~h}$ )

\begin{tabular}{l|l|l|l|l}
\hline 53.0 & 32.9 & 6.7 & 15.5 & \\
\hline
\end{tabular}

AOM (hour required to reach peroxide value 100)

\begin{tabular}{l|l|l|l|l}
\hline 12.0 & 13.0 & 17.0 & 15.5 & \\
\hline
\end{tabular}

*1 Duplicate deodorization experiments.

*2 Key to symbols: * Significant difference (5\% level), ** highly significant difference (1\% level), + no significant difference.

*3 Peroxide value at time of organoleptic evaluation.
Dutton et $a l^{111}$. reported similar results. How = ever, as citric acid is completely decomposed during deodorization at $260^{\circ} \mathrm{C}^{5)}$, Cowan's metal = chelating theory cannot interprete this result. Further clarification is necessary.

On the other hand, citric acid exhibited no synergistic effect on flavor stability when the soybean oil was exposed to fluorescent light. Moser et $a l{ }^{12)}$ reported that the addition of citric acid to soybean oil do not protect the oil against photooxidation. Sattar and Deman ${ }^{13}$ observed the deterioration of oils and fats by fluorescent light, and discussed that spontaneous autoxidation and photooxidation may proceed by different mechanism. Present data support their idea. First, citric acid was ineffective against photooxidation as described above. Second, the photooxidized soybean oil was really tasted "light-struck" as Moser et al. ${ }^{10)}$ expressing, which was completely different from spontaneously autoxidized soybean oil. Third, the soybean oil was extremely deterio $=$ rated by fluorescent light in spite of its small peroxide increment. Inhibition of photooxidation is now a subject of importance since soybean salad and frying oils are usually sold in clear glass or plastic bottles. Therefore, further study of this problem is necessary.

\subsection{Citric acid solubility}

Since it was proved that citric acid improved the stability of soybean oil, solubility of citric acid in the soybean oil was then determined. In general, it is said that a maximum of $50 \mathrm{ppm}$ citric acid can be dissolved in the oil. ${ }^{14)}$ How ever, the authors have been unable to find any report in which citric acid solubility in the oils and fats are determined. So we have estimated the citric acid solubility in the soybean oil (Table-3). Citric acid, 30, 80, and $500 \mathrm{ppm}$, was added into each soybean oil at

Table-3 Solubility of citric acid in the soybean oil (ppm).

\begin{tabular}{c|c|c|c|c|c|c}
\hline \multirow{2}{*}{ Citric addition } & \multicolumn{2}{|c|}{ Initial*1 } & \multicolumn{4}{c}{ Storaged (weeks)*2 } \\
\cline { 2 - 7 } & Before filtration & After filtration & 1 & 2 & 3 & 4 \\
\hline 30 & 22.2 & $18.2(0.2)^{* 3}$ & 15.9 & 16.8 & 17.3 & $16.6(0.5)$ \\
80 & 57.5 & $43.7(0.2)$ & 38.3 & 39.8 & 43.6 & $40.4(0.5)$ \\
500 & 196.0 & $142.7(0.1)$ & 91.6 & 73.4 & 60.7 & $29.2(0.4)$ \\
\hline
\end{tabular}

*1 Citric acid was determined before and after filtration through a filter paper.

*2 Citric acid in the oil was determined after filtration through a filter paper.

*3 Peroxide value. 
$130^{\circ} \mathrm{C}$ during cooling phase of deodorization. These oils were stored in the dark at ambient temperature for 4 weeks.

Considerable amounts of citric acid were deposited on the glass deodorization flask, therefore, e.g., only $196 \mathrm{ppm}$ of citric acid could be found despite $500 \mathrm{ppm}$ addition. When the citric acid content was determined immedi= ately after the deodorization, 22.2, 57.5, and $196.0 \mathrm{ppm}$ had been found in each oil. When the oils were filtered through a filter paper, $19.2,43.7$, and $142.7 \mathrm{ppm}$ of citric acid was found in each oil. Small amount of citric acid was adsorbed by the filter paper and most part of it had passed through the filter paper. When less than $60 \mathrm{ppm}$ citric acid was dissolved in the soybean oil, it had not precipitated after 4 weeks of storage. Although $196 \mathrm{ppm}$ was dissolved in the oil at the initial stage, only $29.2 \mathrm{ppm}$ could be found after 4 weeks of storage. Therefore, it was confirmed that at least $50 \mathrm{ppm}$ of citric acid can de dissolved in the soybean oil after 4 weeks of storage.

The authors, however, consider from the results above that citric acid is not dissolved but just dispersed as a fine particle in the oil. Citric acid is expected to precipitate out after a long period of storage.

\subsection{Optimum citric acid concentration}

Since a maximum of $50 \mathrm{ppm}$ citric acid can be dispersed in the soybean oil, investigations were made to clarify the optimum citric acid concentration for oxidative and flavor stability. Citric acid was added into the soybean oil at $130^{\circ} \mathrm{C}$ during cooling phase of deodorization. Citric acid $(8.5,22.1$, and $49.0 \mathrm{ppm})$ was found in each deodorized oil (Table-4). Similar to the results in Table-2, citric acid was ineffec= tive towards fluorescent light deterioration. The results of $60^{\circ} \mathrm{C}$ oven and $\mathrm{AOM}$ test indi= cated that although citric acid is effective on flavor and oxidative stability its efficiency is independent of its concentration. Conclusion is therefore that existence of small amount of citric acid in the soybean oil improved flavor and oxidative stability. Little citric acid was decomposed by fluorescent light exposure or $60^{\circ} \mathrm{C}$ of storage.

These results, together with the results in Table-2, suggest that citric acid do not function
Table-4 Effect of citric acid concentration on the oxidative and flavor stability of soybean oil.

\begin{tabular}{|c|c|c|c|c|}
\hline Control & $\begin{array}{l}\text { Citric*1 } \\
8.5 \mathrm{ppm}\end{array}$ & $\begin{array}{l}\text { Citric } \\
22.1 \mathrm{ppm}\end{array}$ & $\begin{array}{l}\text { Citric } \\
49.0 \mathrm{ppm}\end{array}$ & $\begin{array}{l}\text { Signifi }=* 2 \\
\text { cant } \\
\text { difference }\end{array}$ \\
\hline \multicolumn{5}{|c|}{ Flavor score at 0 time } \\
\hline $8.0(0.2)$ & $8.2(0.2)$ & $8.0(0.2)$ & $8.4(0.2)$ & + \\
\hline \multicolumn{5}{|c|}{ Fluorescent light exposure for $10 \mathrm{~h}$} \\
\hline $5.3(0.7)$ & $\begin{array}{l}4.9(0.8 \\
7.2)^{* 3}\end{array}$ & & & + \\
\hline $5.5(0.6)$ & & $\begin{array}{r}5.1(0.9 \\
20.9)\end{array}$ & & + \\
\hline \multirow[t]{4}{*}{$5.0(0.6)$} & & & $\begin{array}{r}5.6(0.9 \\
49.0)\end{array}$ & - \\
\hline & $5.4(1.0)$ & $5.8(0.9)$ & & $\div$ \\
\hline & $5.4(1.0)$ & & $5.0(0.8)$ & + \\
\hline & & $5.8(0.9)$ & $5.6(0.9)$ & + \\
\hline
\end{tabular}

After $3 \mathrm{~d}$ storage at $60^{\circ} \mathrm{C}$

\begin{tabular}{l|r|r|r|c}
\hline $4.9(5.8)$ & $\begin{array}{r}6.9(1.0, \\
7.2)\end{array}$ & & & $* *$ \\
& & $\begin{array}{r}7.0(1.3, \\
21.7)\end{array}$ & & $* *$ \\
$5.1(5.9)$ & & & $\begin{array}{r}6.8(1.1, \\
45.2)\end{array}$ & $*$ \\
\hline
\end{tabular}

After $5 \mathrm{~d}$ storage at $60^{\circ} \mathrm{C}$

\begin{tabular}{r|r|r|r|c}
\hline $2.5(15.1)$ & $5.8(2.3$, & & & $* *$ \\
$3.0(16.2)$ & $3.4)$ & & & $* *$ \\
$3.5(14.0)$ & & $5.8(2.9$, & & \\
& & $19.6)$ & & \\
& & & $6.0(3.1$, & $4 *$ \\
& $6.2(2.1$, & $6.2(2.5$, & & + \\
$5.5)$ & $19.6)$ & & + \\
& & $5.6(2.5$, & + \\
& $6.0(2.3$, & & $44.8)$ & + \\
& & $5.9(2.7$, & $5.7(2.4$, & + \\
& & $20.2)$ & $47.0)$ & + \\
\hline
\end{tabular}

$\mathrm{AOM}$ (peroxide value after $8 \mathrm{~h}$ )

\begin{tabular}{l|l|l|l|l}
\hline 49.8 & 6.8 & 6.0 & 5.9 & \\
\hline
\end{tabular}

$\mathrm{AOM}$ (hour required to reach peroxide value 100)

\begin{tabular}{l|l|l|l|}
\hline 12.0 & 16.5 & 16.5 & 16.5 \\
\hline$* 1$ & Citric acid found in the oil. \\
$* 2$ & For explanation of symbols, see Table- 2 . \\
$* 3$ & $\begin{array}{l}\text { Peroxide value and citric acid content at time } \\
\text { of organoleptic evaluation. }\end{array}$
\end{tabular}

as an acidic synergist. Although a very small amount of iron was found in the soybean oil, citric acid may act as a metal-inactivating agent as Cowan et al. ${ }^{1)}$ insist. On the oher hand, citric acid may inhibit the antioxidant catalysis 
of peroxide decomposition as privett et al..$^{4)}$ described. So research is needed to elucidate the mechanism of citric acid's synergisms.

\section{Acknowledgment}

The authors are grateful to Mr. Noriji Ōnuki of Hohnen Oil Co. Ltd. for his helpful advice in connecs tion with GLC; to Miss Emiko Seki for invaluable assistance and to the members of the taste panel for their continuing interest and participation.

(Received March 11, 1978)

\section{References}

1) J.C. Cowan and C.D. Evans, "Autoxidation and Antioxidants", ed. by W.O. Lundberg, Vol. 2, John Wiley and Sons Inc., New York (1962) p. 593.

2) W.O.Lundberg," Symposium on Foods: Lipids and Their Oxidation", ed. by H.W. Schultz, Avi Pub. Co., Westport (1962) p. 31.

3) H.W. Lemon, R.M. Knapp, and A.H. Allman, Can. J. Research, F 28, 453 (1950).

4) O.S. Privett and F.W. Quackenbush, J. Am. Oil Chem. Soc., 31, 321 (1954).

5) K. Miyakoshi, and M. Komoda, Yukagaku, 27, 381 (1978).

6) J.P. Nelson and A.J. Milun, J. Am. Oil Chem. Soc., 45, 848 (1968).

7) C.D. Evans, G.R. List, and L.T. Black, $J$. Am. Oil Chem. Soc., 48, 840 (1971).

8) K. Miyakoshi and M. Komoda, J. Am. Oil Chem. Soc., 54, 331 (1977).
9) H.A. Moser, C.M. Jaeger, J.C. Cowan, and H.J. Dutton, J. Am. Oil Chem. Soc., 24, 291 (1947).

10) H.A. Moser, C.D. Evans, J.C. Cowan, and W.F. Kwolek, J. Am. Oil Chem. Soc., 42, 30 (1965).

11) H.J Dutton, A.W. Schwab, H.A. Moser, and J.C. Cowan, J. Am. Oil Chem. Soc., 26, 441 (1949).

12) H.A. Moser, C.D. Evans, G. Mustakas, and J.C. Cowan, J. Am. Oil Chem. Soc., 42, 811 (1965).

13) A. Sattar and J.M. Deman, J. Am. Oil Chem. Soc., 53, 473 (1976).

14) H.W. Vahlteich, C.M. Gooding, C.F. Brown, and D. Melnick, Food Tech., p. 6 Jan. (1954).

大豆油の風味のもどりに及ぼすクエン酸の効果 宮腰宏治・获田 衛・松原繁左右

大豆油を脱臭したときクエン酸を添加した。大豆油中 のクエン酸含量を $5 \%$ シリコーン OV-17 GLC にて定 量し, また大豆油の風味及び酸化安定性に及ぼすクエン 酸の影響について検討した。大豆油をけい光燈照射にて 劣化させたとき, クエン酸は風味の劣化を防止するこ上 はできなかった。一方, 大豆油を自動酸化的に劣化させ たとき，クエン酸は大豆油の酸化及び風味安定性を著し く改善した。しかしながら，その効果はクエン酸濃度 には関係がなかった。大豆油へのクエン酸の溶解度を測 定した。4 週間の保存試験の結果から，少なくとも50 $\mathrm{ppm}$ のクエン酸が大豆油中に溶解できることがわかっ た。 